This document was prepared in conjunction with work accomplished under Contract No. DE-AC09-96SR18500 with the U.S. Department of Energy.

This work was prepared under an agreement with and funded by the U.S. Government. Neither the U. S. Government or its employees, nor any of its contractors, subcontractors or their employees, makes any express or implied: 1 . warranty or assumes any legal liability for the accuracy, completeness, or for the use or results of such use of any information, product, or process disclosed; or 2 . representation that such use or results of such use would not infringe privately owned rights; or 3 . endorsement or recommendation of any specifically identified commercial product, process, or service. Any views and opinions of authors expressed in this work do not necessarily state or reflect those of the United States Government, or its contractors, or subcontractors. 


\section{Re: Hydraulic Conductivity of Essentially Saturated Peat}

The Savannah River National Laboratory measured the hydraulic conductivity of peat samples using method ASTM D4511-00. Four samples of peat were packed into 73mm diameter plastic tubes and saturated from the bottom up with water. The columns were packed with Premier ProMoss III TBK peat to a dry density of approximately $0.16 \mathrm{gm} / \mathrm{cc}$ $\left(10 \mathrm{lb} / \mathrm{ft}^{3}\right)$. One column was packed using oven dried peat and the other 3 were packed using as delivered peat. The oven dried sample was the most difficult to saturate. All of the peat samples expanded during saturation resulting in a sample length $(\mathrm{L})$ that was longer than when the sample was initially packed. Table 1 contains information related to the column packing. After saturation the hydraulic conductivity test was conducted using the apparatus shown in Figure 1. Three of the samples were tested at 2 different flow conductions, 1 high and 1 low. Table 2 and Figure 2 contain the results of the hydraulic conductivity testing. Each test was run for a minimum of 40 minutes to allow the test conditions to stabilize. The hydraulic conductivity at the end of each test is reported as the hydraulic conductivity for that test.

The hydraulic conductivity of the 4 peat samples is $0.0052 \pm 0.0009 \mathrm{~cm} / \mathrm{sec}$. This result compares well with the hydraulic conductivity measured in the pilot scale peat bed after approximately 2 months of operation. The similarity in results between the dry pack sample and moist pack samples shows the moisture content at the time of packing had a minimal effect on the hydraulic conductivity. Additionally, similarity between the results shows the test is reproducible. The hydraulic conductivity results are similar to those reported by other tests of peat samples reported in the literature. 
Page 2 of 3

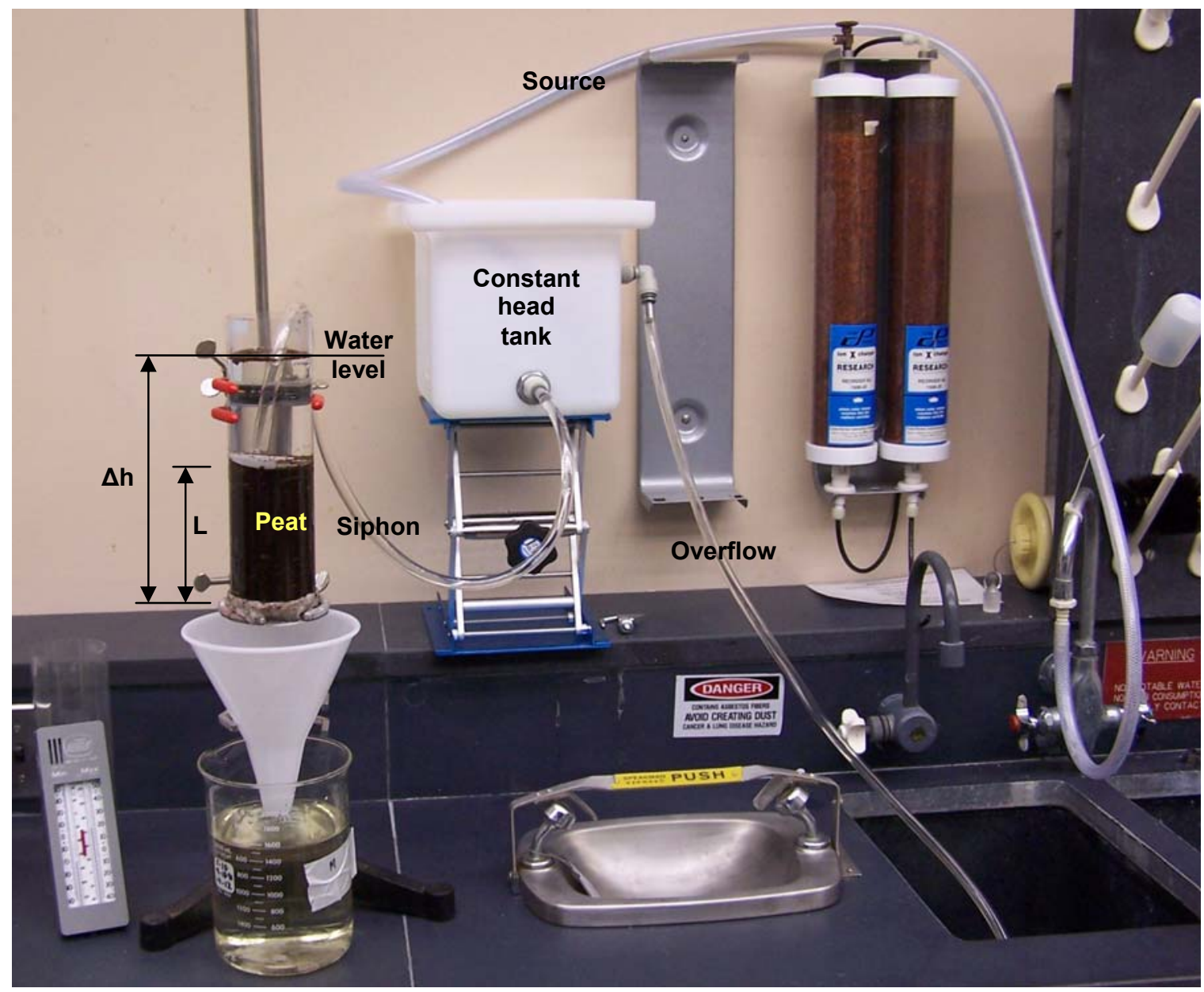

Figure 1 Apparatus used for measuring hydraulic conductivity of essentially saturated peat.

Table 1 Test conditions.

\begin{tabular}{|c|c|c|c|c|c|c|}
\hline \multirow[b]{2}{*}{ Sample } & \multirow[b]{2}{*}{$\begin{array}{c}\text { Diameter } \\
(\mathrm{cm})\end{array}$} & \multicolumn{2}{|c|}{ As packed } & \multirow{2}{*}{$\begin{array}{l}\text { Dry bulk } \\
\text { density, } \\
\text { (gm/cc) }\end{array}$} & \multicolumn{2}{|c|}{ Saturated } \\
\hline & & $\theta(w / w)$ & $\begin{array}{l}\text { Length, } \\
\text { L (cm) }\end{array}$ & & $\theta(w / w)$ & $\begin{array}{l}\text { Length, } \\
\mathrm{L}(\mathrm{cm})\end{array}$ \\
\hline Bag 1, Sample 1 & 7.3 & 0 & 11 & 0.17 & $\mathrm{~nm}$ & 13.3 \\
\hline Bag 2, Sample 1 & 7.3 & 0.61 & 11 & 0.16 & $\mathrm{~nm}$ & 12.0 \\
\hline Bag 2, Sample 2 & 7.3 & 0.61 & 11 & 0.16 & 0.88 & 13.2 \\
\hline Bag 3, Sample 3 & 7.3 & 0.61 & 11 & 0.17 & 0.86 & 14.0 \\
\hline
\end{tabular}

Note: $1 \mathrm{gm} / \mathrm{cc}=62.43 \mathrm{lb} / \mathrm{ft}^{3}$

$\theta=$ gravimetric water content 
WSRC-STI-2008-00113, Rev. 0

Page 3 of 3

Table 2 Test results.

\begin{tabular}{|c|c|c|c|c|c|c|}
\hline \multirow[b]{2}{*}{ Sample } & \multicolumn{2}{|c|}{$\Delta \mathrm{h}, \mathrm{cm}$} & \multicolumn{2}{|c|}{ Flowrate (cc/sec) } & \multicolumn{2}{|c|}{$\begin{array}{c}\text { Hydraulic } \\
\text { Conductivity, K } \\
\text { (cm/sec) }\end{array}$} \\
\hline & 1 & 2 & 1 & 2 & 1 & 2 \\
\hline Bag 1, Sample 1 & 21.3 & na & 0.28 & na & 0.0042 & na \\
\hline Bag 2, Sample 1 & 21.3 & 15 & 0.39 & 0.24 & 0.0052 & 0.0046 \\
\hline Bag 2, Sample 2 & 17.7 & 22.5 & 0.39 & 0.43 & 0.0070 & 0.0061 \\
\hline Bag 3, Sample 3 & 21.6 & 16.2 & 0.32 & 0.22 & 0.0049 & 0.0045 \\
\hline
\end{tabular}

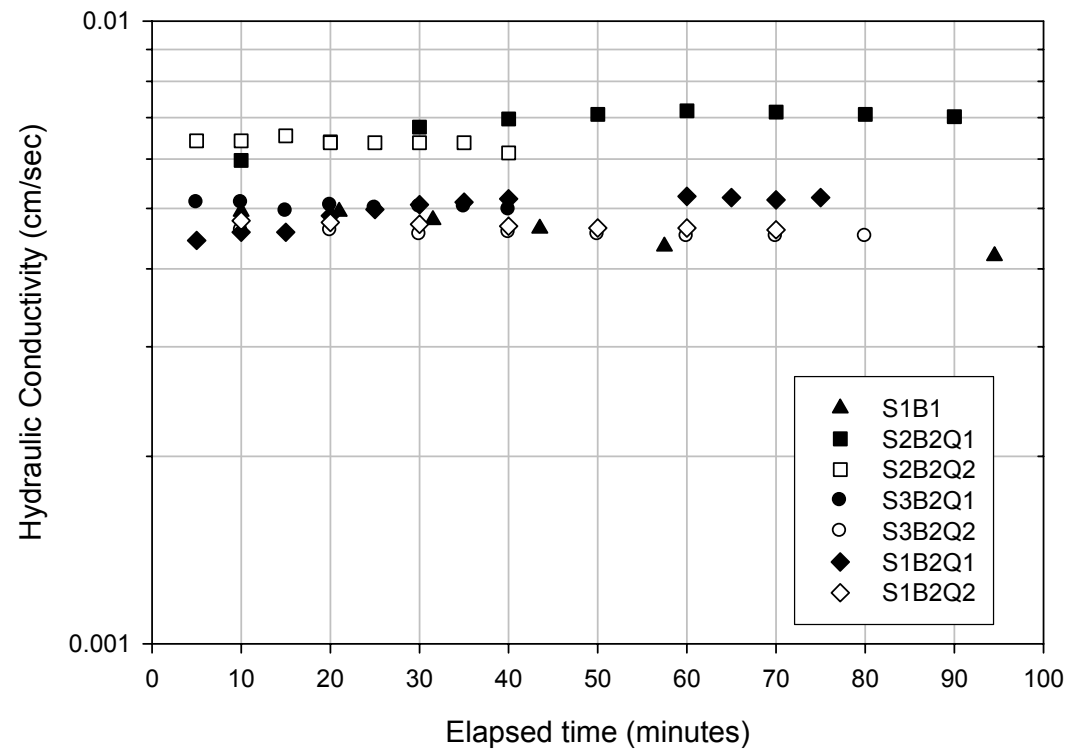

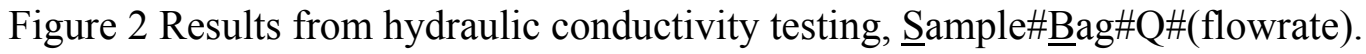

